\title{
Telling Stories: Clare, Folk Culture, and Narrative Techniques
}

\author{
John Goodridge
}

Nottingham Trent University

Let me start by quoting two critical comments from Clare's letters. Firstly, on Thomas Percy's Reliques of Ancient English Poetry (1765), which he read in July 1820. He is writing to his publisher Hessey:

D[rury] has sent me 3 vols calld 'Percys Relics' there is some sweet Poetry in them \& I think it is the most pleasing book I ever happend on the tales are familiar from childhood all the stories of my grandmother \& her gossiping neighbours I find versified in these vols ${ }^{1}$

Secondly, summarising the achievement of Robert Bloomfield (1766-1823), shortly after Bloomfield's death:

He is in my opinion our best Pastoral Poet. His 'Broken Crutch,' 'Richard and Kate,' \&c. are inimitable and above praise. ${ }^{2}$

Clare's enthusiasm for story poems such as those he praises in Percy and Bloomfield, and his own habitual commitment to the narrative mode, is striking, even in an age which produced such bold narrative experiments as 'The Rime of the Ancient Mariner,' 'The Thorn' , and 'Don Juan'. There is an overarching narrative in Clare's work, a multistranded story of betrayal, loss and impoverishment which runs through all his poetry and prose. And he is also forever 'telling stories,' both in recognisable narrative forms such as ballads, folk-songs, and longer stanzaic poems, and in less predictable ways. One of best known of the poems which the critic Johanne Clare dubbed Clare's 'enclosure elegies,' is a story-poem in ballad-metre, the autobiography of a piece of land:

Im swordy well a piece of land

Thats fell upon the town

Who worked me till I couldnt stand

And crush me now Im down ${ }^{3}$

And if we dip our hands into the stream of irregular sonnets which poured from Clare's pen in the 1830s, we come up with material such as the five-sonnet sequence usually known as 'The Badger,' a narrative of ritualised communal cruelty: 
When midnight comes a host of dogs \& men

Go out $\&$ track the badger to his den

\& put a sack within the hole \& lye

Till the old grunting badger passes bye...

They get a forked stick to bear him down

\& clapt the dogs \& bore him to the town

\& bait him all the day with many dogs

\& laugh \& shout \& fright the scampering hogs 4

Apart from one usefully introduced selection of Clare's Cottage Tales, published in the UK in 1993, the narrative aspect of his art has been neglected, perhaps because narrative poetry has generally been out of favour since the age of Masefield. I cannot remedy that neglect in a short paper -- Clare really needs a Propp or a Zipes to classify and analyse properly the riches of his narrative work -- but I shall try here to isolate some key features of the way Clare tells stories in verse, and draw one or two conclusions about the process.

Clare's comments on Percy offer useful clues. The 'most pleasing book I ever happend on' is loved for its affinity to 'the stories of my grandmother \& her gossiping neighbours'. As this suggests, the roots of Clare's narrative poetry lie deep in an essentially oral and popular tradition of tale-telling which Percy had partly captured in his anthology. Clare found the oral story-telling tradition locally in characters like Will Farrow the shoemaker, 'a village wit a very droll fellow a sort of Easop' who was 'famous for a joke and a droll story'. Farrow was a maker of new stories, an instant chronicler, who Clare says ' had a peculiar knack at making up laughable anecdotes on any circumstance which happend in the village'. 5 We also know that Clare was enormously influenced by the women he accompanied in his field-work as a child, particularly Mary Bains the cowherd, described by Frederick Martin as an 'ancient lady' whom Clare met daily when, from the age of seven, he was sent out to tend sheep and geese:

She was an extraordinary old creature, this Mary Bains, commonly known as Granny Bains. Having spent almost her whole life out of doors, in heat and cold, storm and rain, she had come to be intimately acquainted with all the signs foreboding change of weather, and was looked upon by her acquaintances as a perfect oracle. She had also a most retentive memory, and being of a joyous nature, with a bodily frame that never knew illness, had learnt every verse or melody that was sung within her hearing, until her mind became a very storehouse of songs. 6 
Individuals like Granny Bains were the guardians of narrative and folkloric wisdom, the unofficial educators and archivists of rural popular culture. Clare introduces such a teller of tales and keeper of wisdom as the framing narrator in one of his narrative poems, 'The Cross Roads: or, the Haymaker's Story,' printed in The Village Minstrel (1821), and set in a specific rural working environment. The opening passage of the poem carefully sets up her authority, not only as the controller of the narrative, but as the representative of age and experience, set against the giddiness of youth:

Stopt by the storm that long in sullen black

From the south west staind its encroaching track

Haymakers hussling from the rain to hide

Sought the grey willows by the pasture side

\& there while big drops bow the grassy stems

\& bleb the withering hay with pearly gems

Dimple the brook \& patter in the leaves

The song \& tale an hours restraint relieves

$\&$ while the old dames gossip at their ease

\& pinch the snuffbox empty by degrees

The young ones join in loves delightfull themes

Truths told by gipsys \& expounded dreams

\& mutterd things kept secrets from the rest

Of sweethearts names \& who they love the best

\& dazzling ribbons they delight to show

The last new favours of some weigling beau

That with such treacherey trys their hearts to move

\& like the highest bribes the maidens love

The old dames jealous of their wisperd praise

Throw in their hints of mans deluding ways

\& one to give her counsels more effect

\& by example illustrate the fact

Of innoscence oercome by flattering man

Thrice tappd her box \& pinchd \& thus began

"Now wenches listen \& let lovers lye

"Yell hear a story ye may profit bye

"Im your age threble wi some oddments to't

"\& right from wrong can tell if yell but do't

"Ye neednt giggle underneath your hats 
"Mines no joke matters let me tell you that

"So keep yer quiet till my storys told

"\& dont despise yer betters cause theyre old

"I wish ye well upon my soul I do

"\& just another pinch \& Ill pursue

"That grave yeve heard off were the four roads meet

"Were walks the spirit in a winding-sheet

"Oft seen at night by strangers passing late

"\& tarrying neighbours that at market wait

"Stalking along as white as driven snow

"\&s longs ones shadow when the sun is low

"The girl thats buried there I knew her well

"\& her whol[e] history if yell hark can tell (1-42) 7

The story which she then tells is a tragic account of a young woman's betrayal in love, ending in suicide. The tale ends with more moralising warnings by the narrator. She has, as we can see, tremendous moral authority and rhetorical presence. She is a Granny Bains figure dispensing wisdom with a pinch of snuff, demanding attention and respect from the young women, under the guise of beguiling time and weather. The authority she claims for her age and experience is strongly complemented by the narrative intelligence finely displayed here, for example in the Hamlet-like claim to first-hand authority in 'I knew her well,' and the impressive promise of 'her whol[e] history'.

Her story is didactic in that she is clearly warning the young women around her about the seriousness of being sexually betrayed, and of course to the would-be poet, the John Clare in her audience, she is offering the basic narrative archetype of the betrayal story. In fact it is striking just how many of Clare's narrative poems concern sexual betrayal, whose victims range from the silenced and shunned figure of 'once-beguiled Kate,' in 'St Martin's Eve,' who 'made one slip in love and played the fool / And [is] since condemned to live without a mate,' to Sally Grey in 'The Sorrows of Love,' at the head of whose sad tale Clare quotes Shakespeare: 'Good shepherd tell this youth what tis to love / It is to be all made of sighs and tears'. 8

Why does Clare place such emphasis on narratives of sexual betrayal? One reason might be that there is an obvious metaphorical link between the betrayal of woman and Clare's most famous theme, the betrayal of the landscape. We can say that his poetry is constantly concerned with loss and betrayal, human (male) rapaciousness, the politics of exploitation. It might also relate to the theme of control (or lack of control) over one's 
environment, and one's existence and destiny. For most people in the rural world Clare describes, the choice of a marriage partner was the most important area of their existence over which they might have any real control. Employment, housing, living conditions, economic and social status, even leisure activities were only controllable within very narrow imposed limits. Hence the ubiquity and variety of divinatory rituals and occasions for determining the name of one's future beloved which occur in Clare's poems, such as the gypsies and dreams routinely mentioned in the opening to 'The Cross Roads,' quoted above. Betrayal narratives are a symptom of the ever-present fear of getting it wrong. In a world of limited choice a mistake is likely to prove tragic, particularly for young women, who are as vulnerable in Clare's world to exploitation and betrayal, especially by someone of a higher social class, as they are in the world of Tess of the Durbevilles.

The two Bloomfield poems Clare praises so highly cast an interesting light on this theme and on Clare's narrative techniques and concerns more generally, and we may briefly consider them here. 'Richard and Kate' tells of an old couple who go to the fair, meet up with their children and grandchildren, and have a celebratory drink. This might seem thin fare for a narrative poem, but the celebration of harmonious family-life, the idyll of three generations being alive and happy together, takes on a particular acuteness and a significance when one considers how rare such an occurrence must have been in an age of high infant mortality and rural poverty. ${ }^{9}$ It is a story of family relationships and life itself 'going right' -- literally and straightforwardly a life-affirming poem -- and Clare has parallel narratives of celebration, for example in his poem 'Going to the Fair'.10

'The Broken Crutch,' by contrast, is a 'going wrong,' a betrayal narrative, albeit one which is rescued by a happy ending. It concerns a young woman of humble origins with whom the local squire has fallen in love, and the anxieties of her lame father and his brother (and indeed the entire rural community since everyone is talking about it), as to whether the squire will marry her as he seems to intend, or betray her as most expect. We begin with her father's parting words to his daughter as she leaves home to go into service:

"I tell you, Peggy," said a voice behind

A hawthorn hedge, with wild briars thick entwin'd, Where unseen trav'llers down a shady way Journey'd beside the swaths of new-mown hay, "I tell you, Peggy, 'tis a time to prove "Your fortitude, your virtue, and your love. "From honest poverty our lineage sprung, 
"Your mother was a servant quite as young;--

"You weep; perhaps she wept at leaving home,

"Courage, my girl, nor fear the days to come.11

This takes place 'behind' the hedge, and in placing us, the readers, out of sight from the father and daughter, Bloomfield puts us in the position of the young Squire, Herbert Brooks, who overhears the conversation. We must observe things from his viewpoint and decide for ourselves whether his response to the father's words is to be a gleeful twirl of his villainous moustache, or a sigh of honest sympathy for Peggy's plight. This careful dramatic and cultural 'placing' of the characters in the story, is typical of Bloomfield and indeed of Clare. Both are interested in the scene of the story-telling as much as the scene of the drama itself. We see this again and again in Clare, where the telling of the story and the person who tells are vital elements in the poem. In 'The Two Soldiers' in the Cottage Tales volume, for example, Clare devotes about half the length of the poem to the story-teller and the manner of telling, interweaving it subtly with the story, and even placing himself as the super-narrator watching the narrator 'Goody' as she pauses to reflect:

Now goody let the story stop

A minute in her mind

While louder in the chimney top

\& louder got the wind

She said what many may have said

In such a night what joy

To have a house above their heads

To keep them warm \& dry $(101-8)^{12}$

This meta-narrative and concern with precise details of the story-telling suggest that it had a ritual function in the rural community, or at least that its rituals were as important as the story itself. I am also struck by the dramatic, even melodramatic way that Clare builds up the sense of uncanniness and suppressed violence both here and in another narrative poem, 'The Lodge House', partly through the demeanour of the narrator.

Clare can also write happy endings in which fear and antagonism melt away into celebration, like the one Bloomfield supplied for 'The Broken Crutch'. In fact he uses a range of dramatically appropriate ways of concluding the narratives. An interesting example is 'The Sorrows of Love or The Broken Heart'. As with 'The Cross Roads,' this is a story told by an old woman about a female friend from her youth who had died, Sally 
Grey. It ends with the narrator's sorrow and emotional exhaustion at its telling, as she waves away the 'rustling' printed 'penny stories' (25) with which her young audience is eagerly waiting to reciprocate (and, one might say, to supplant her and her narrative, since printed tales are the sign of a new way of story-telling which will soon usurp the old woman's oral tradition of narrative):

"Nay keep your work tis not worth while to leave

"Ill sit and hear it on to morrow eve

"For even if the night woud time alow

"My hearts so sad I cannot hear it now

"Ive talkd till I have almost tird my tongue

"Folks say old womens tales are always long

"So here Ill end \& like it as ye may

"I wish ye better luck then sally grey"

She ceasd her tale \& snuffd the candle wick

Lifting it up from burning in the stick

That soon had faild to light her story out

Had she continued spinning it about

Then laid her knitting down \& shook her head

\& stoopd to stir the fire \& talk of bed (551-64) 13

One does not need to labour the point that Clare is making delicately here, in the images of lights going out, things closing down. He is a writer as sensitive to old age and the 'closure' of human life, as he is to the subtleties of narrative closure.

In Clare's world, to summarise, narrative fulfils important social functions. It is (as story-telling always is) a distraction and a way of beguiling the time. But it is also a ritual, imaginative act of self-assertion, a cathartic gesture, a way of reinforcing a sense of existence in a fairly grim world. ${ }^{14}$ And it is an education, an unofficial but vital way of passing on important information in the continuous battle against lack of control over one's life. It is a way of recording and celebrating finite lives, and so saving them and the knowledge they represent from oblivion, and it is a way of fostering understanding and empathy for the stories themselves, and the lives they represent. Clare often focuses on the intensely engaged responses of the listeners to stories, and in doing so shows us something of the richness and power of the oral narrative tradition which, like Percy and Bloomfield before him, he is re-inscribing into a literary culture. 


\section{NOTES}

1. Clare to J.A. Hessey, 4 Jul 1820, in The Letters of John Clare, ed. Mark Storey (Oxford: Clarendon Press, 1985), p. 82.

2. Clare to Allan Cunningham, 9 Sep 1824, Letters, p. 302.

3. From 'The Lament of Swordy Well,' in John Clare, Selected Poetry and Prose, ed. Merryn and Raymond Williams (London: Methuen, 1986), p. 93.

4. John Clare, Northborough Sonnets, ed. Eric Robinson, David Powell and P.M.S. Dawson (Ashington and Manchester: Carcanet and the Mid-Northumberland Arts Group, 1995), p. 27.

5. John Clare, By Himself, ed. Eric Robinson and David Powell (Ashington and Manchester: Carcanet and the Mid-Northumberland Arts Group, 1996), pp. 64-5.

6. Frederick Martin, The Life of John Clare [1865], Second Edition with an Introduction and Notes by Eric Robinson and Geoffrey Summerfield (London: Frank Cass, 1964), p. 8. See also June Wilson, Green Shadows: The Life of John Clare (London: Hodder and Stoughton, 1951), pp. 22-3.

7. John Clare, Cottage Tales, ed. Eric Robinson, David Powell and P.M.S. Dawson (Ashington and Manchester: Carcanet and the Mid-Northumberland Arts Group, 1993), pp. 18-19.

8. John Clare, ed. R.K.R. Thornton (London: J.M. Dent, 1997), Everyman's Poetry series, p. 38; Cottage Tales, p. 82.

9. See John Lucas, 'Bloomfield and Clare,' in The Independent Spirit: John Clare and the self-taught tradition, ed. John Goodridge (Helpston: The John Clare Society and the Margaret Grainger Memorial Trust, 1994), pp. 55-68 (63-4).

10. Cottage Tales, pp. 55-71. 'Richard and Kate' opens Bloomfield's second publication, Rural Tales, Ballads and Songs (London: Vernor and Hood, and Longman and Rees, 1802), pp. [1]-14. 
11. Robert Bloomfield, Wild Flowers; or, Pastoral and Local Poetry (London: Vernor, Hood, and Sharpe; Longman, Hurst, Rees and Orme, 1806), p. 51.

12. Cottage Tales, pp. 10-17 (13).

13. Cottage Tales, pp. 82-97 (82, 97).

14. I discuss a detailed example of this process in my forthcoming article, 'Out There in the Night: Rituals of Nurture and Exclusion in Clare's "St Martin's Eve"'. 